\title{
NANO-BIOCOMPLEXES BASED ON OLIGOSACCHARIDES AND THEIR DERIVATES*
}

Milorad Cakić ${ }^{\text {**}}$, Goran S. Nikolić ${ }^{1}$, Žarko Mitić 2 , Slobodan Glišić1 Dragan Cvetković ${ }^{1}$, Ljiljana Stanojević ${ }^{1}$

(ORIGINAL SCIENTIFIC PAPER) UDC 547.458:541.49

1University of Niš, Faculty of Technology, Leskovac, Serbia

2University of Niš, Faculty of Medicine, Niš, Serbia

Nanotechnology refers to the branch of science and engineering dedicated to materials, having dimensions in the order of $100^{\text {th }} \mathrm{nm}$ or less. Many ions of transition or noble metals can form complex compounds of nanoparticle size. These compounds are of scientific and practical interest, because of their proven or potential application in different areas. Nano-biocomplexes of iron, copper, cobalt and silver with oligosaccharides and their derivatives are important in medicine, cosmetics and veterinary medicine. The development of new nano-biocomplexes based on oligosaccharides and their derivatives and non-toxic or "green" silver nanoparticles syntheses, the influence of the ligand constitution on the synthesis outcome, stability, structure and pharmaco-biological properties are the subject of this paper.
Keywords: nano-biocomplexes, iron, copper, cobalt, silver, oligosaccharides, pharmaco-biological properties

\section{Introduction}

Materials of nano dimension, from 1 to $100 \mathrm{~nm}$, have specific characteristics that differ from those of the same chemical composition with macroscopic dimensions. Metal nanoparticles, (MNPs), have unique catalytic, electrical, magnetic, optical and mechanical characteristics, as well as biological activity [1-3], thanks to the large specific surface area in terms of volume and large surface energy. Many ions of some transition metals such as copper, iron, cobalt can form complex nano size particles under appropriate reaction conditions. Ions of precious metals like silver, gold, palladium, platinum, titanium in the presence of a reducing agent, having a role of the stabilizing agent at the same time, can also form the nanoparticles. Complex compounds are not only of scientific but also of practical interest since many of them have found application not only in different industrial areas but also in medicine, cosmetics, veterinary and nanotechnologies [4-9]. A lot of investigations of synthesis and characterization of different metal complexes with biological ligands or synthetic ligands, serving as a model of complex biomolecular structures, has been conducted. Bioligands, or synthetic ligands are mainly natural chemical compounds of macromolecular type, such as oligosaccharides, proteins, and nucleic acids. In this group of products, chemical compounds of polysaccharide type or their derivatives containing cations of different transition biometals $(\mathrm{Cu}(\mathrm{II})$, $\mathrm{Co}(\mathrm{II}), \mathrm{Zn}(\mathrm{II})$ and $\mathrm{Fe}(\mathrm{III})$ ) with proven or potential pharmacological activity, are very important [10-12]. The preparations based on these compounds are used in human and veterinary medicine since they contain polysaccharide as an energy source and a bio-element as a significant factor in the metabolic processes. Commercial parenteral preparations based on the water-soluble complex of $\mathrm{Fe}(\mathrm{III})$ with dextran oligosaccharides are used in the treatment of sideropenic anemia. Such complexes can also be obtained with other polysaccharide-type ligands, such as inulin (polyfructofuranoside) and pullulan (polymaltotriosis). Except for iron, the presence of other hematopoietically active biometals, such as copper, cobalt and zinc, is necessary for the successful medical treatment. In human and veterinary medicine, the products with polymicroelements are of special interest, since they provide a complex treatment of different diseases simultaneously.

Nano particles of precious metals have practical applications in various fields. Silver, gold, palladium, and platinum nanoparticles are particularly important in the fields of electronics, medicine, pharmacy and cosmetics. For this reason, the processes of synthesis, characterization and application of such particles have been studied intensively over the past decades. Among the various metal nanoparticles, silver nanoparticles (AgNPs) are practically used particularly for their potential antibacterial, antifungal and antiproliferative, antioxidant and anticancer activities in different areas [12-21]. Silver nanoparticles can be obtained by different methods [22]. Increasing application of silver nanoparticles based on environmental principles implies, among other things, an increasing need for nontoxic or "green" syntheses. One of the ways to develop

*The paper was presented at 13th Symposium with international participation "NOVEL TECHNOLOGIES

AND ECONOMIC DEVELOPMENT" as a plenary lecture, Faculty of Technology in Leskovac,

18-19 October, 2019

** Author adress: dr Milorad Cakić, Faculty of Technology,

16000 Leskovac, Bulevar oslobodjenja 124, Serbia

E-mail: cakicm@yahoo.com

The manuscript received: Jul, 23, 2019. 
the non-toxic syntheses is the usage of a biopolymer as a matrix. Polysaccharides are the most widely used polymers from the following biopolymers: dextran, pullulan, alginate, agar, starch, chitosan, and glycogen, as well as extracts obtained from natural products [23].

The development of new nano-biocomplexes based on oligosaccharides and their derivatives, as well as the influence of the ligand constitution on the synthesis outcome, stability, structure and pharmaco-biological properties, are the subjects of this paper.

\section{Iron(III) complexes with Dextran, Pullulan and Inulin oligomers}

\section{Synthesis of complexes}

Many preparations based on the organic and inorganic bivalent and trivalent iron compounds are used for the prevention and treatment of sideropenic anemia in human and veterinary medicine. A wide spectrum of preparations was pharmacologically and clinically examined into details earlier, while the solutions of trivalent iron (polynuclear ironoxyhydroxide, with $\beta_{2}-\mathrm{FeOOH}$ macromolecule) with carbohydrates and their derivatives have been used as parenteral antianemics more recently [24]. Water soluble $\mathrm{Fe}(\mathrm{III})$ polynuclear complexes can be produced from low molecular weight dextran (LMD), its hydrated derivative (RLMD), and other oligosaccharide type ligands such as hydrated low molecular pullulan (polymalthotriose, RLMP) and inulin (polyfructofuranoside, IN).

(a)

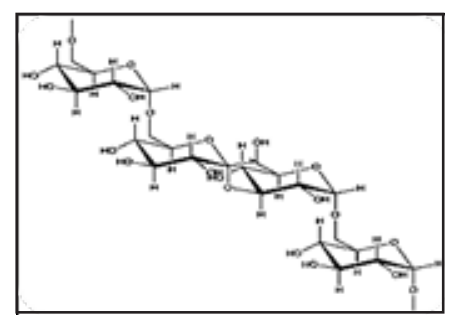

(b)

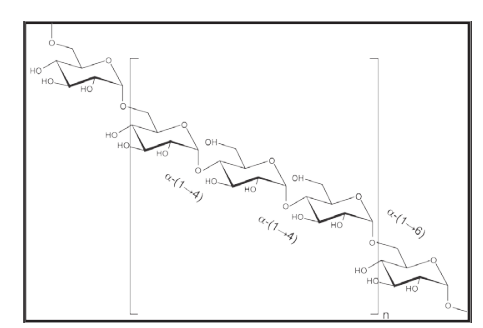

(c)

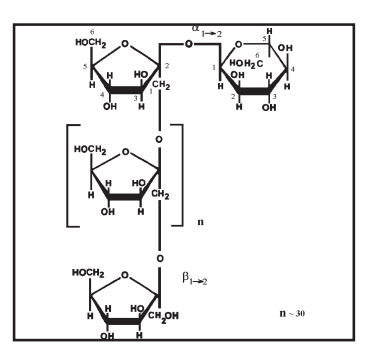

Figure 1. Structure of polysaccharide dextran with $\alpha-(1 \rightarrow 6)$ glycosidic linkages in main chain; branching with $\alpha-(1 \rightarrow 3)$ glycosidic linkage, a) polysaccharide pullulan with $\alpha-(1 \rightarrow 6)$ repeating dominant maltotriose units, b) and inuline c)
Molecular forms of these oligosaccharides are presented in Fig 1. A new, so called single-step synthesis process, which differs from the two-step process, was used in the preparation of the component $\beta_{2}-\mathrm{FeOOH}$ for the synthesis of complexes with RLMP, RLMD and IN [25-28]. The optimal properties of the ligand and complexes as potential parenteral antianemics were defined by studying the influence of various physico-chemical factors on the synthesis course and outcomes for the synthesis of the complex with inulin, dextran and pulIulan with the optimal $\mathrm{Mw}$ in the range of 2.000-4.000, 3.000-6.000, and 5.000-9.000 gmol g $^{-1}$, respectively, and reducing sugar content to less than $0.5 \%$. The optimum iron : ligand ratio was $1: 5, \mathrm{pH} 10$, synthesis at boiling temperature for $30-120 \mathrm{~min}$ [27].

\section{Gel chromatography of the complex}

Gel chromatographic (GPC) investigations on Sephadex G-75 columns showed the presence of 2 fractions in the complexes: (1) the fraction of true complex with bound ligand (colored fraction of about $14 \mathrm{~cm}^{3}$ with a molar mass higher than $100.000 \mathrm{gmol}^{-1}$ and a fraction of 60 $90 \%$ ) and (2) a free ligand fraction (a colorless fraction of about $18 \mathrm{~cm}^{3}$ with a molar mass less than $2.000 \mathrm{gmol}^{-1}$ with a contribution of $10-40 \%$ ).

\section{Spectra-structural correlations}

The structure of polynuclear Fe(III) complexes with oligosaccharides was not explained in details. Namely, $\beta_{2}-\mathrm{FeOOH}$ and oligosaccharides can be bound by covalent or hydrogen bond [24,29]. The type of bonding in the complex cannot be verified with certainty by spectroscopic method because of the covering band effect from free oligosaccharides. Iron(III) complexes with dextran, pullulan and inulin oligomers had been studied earlier by UV-Vis methods [26]. These complexes had shown an absorption maximum at $\lambda_{\max }=505 \mathrm{~nm}$ with the crystal split energy of $2.56 \mathrm{eV}$, and the crystalline field splitting energy of $E m=237.02 \mathrm{kJmol}^{-1}$ (Vis), corresponding to $p \rightarrow d$ transition of Fe (III) with octahedral coordination [26]. FTIR spectroscopy was used for further investigation of the structure. The presence of $\beta_{2}-\mathrm{FeOOH}$ in the complex structure was verified by the band at $\sim 700 \mathrm{~cm}^{-1}$ of $\mathrm{y}(\mathrm{OH})$ vibrations [30]. The complexes, isotopic exchanged and refined by gel-chromatography, were confirmed as hydrates by FTIR study. Water protons take part in the formation of weak hydrogen bonds; Ow... O distances were estimated as 280 and 283 pm for inulin and their complex, respectively. In the case of dextran and pululan the distances were 284 and 290 pm, respectively [31]. The FTIR spectra of RLMD, RLMP and their $\mathrm{Fe}$ (III) complexes showed two bands at 930 and 850 $\mathrm{cm}^{-1}$ in the $\mathrm{y}(\mathrm{CCH})$ region $\left(1000-700 \mathrm{~cm}^{-1}\right)$, characteristic for ${ }^{4} \mathrm{C}_{1}$ conformation of glucopyranosyl units. Significant shifts was noticed in $1500-1300 \mathrm{~cm}^{-1}$ region, characteristic for methylene groups bending vibration. The decrease of bands intensity from methylene groups, $\delta(\mathrm{CH})$ at $\sim 1450 \mathrm{~cm}^{-1}$ and $\mathrm{v}(\mathrm{CH}) \sim 2900 \mathrm{~cm}^{-1}$, was controlled by 
C5-C6 rotation in the glucopyranose ring of isomers due to dipole moment changes characteristic for this conformation [31]. In the FTIR spectra of gel-refined compounds, bands from $\mathrm{v}(\mathrm{OH})$ vibration was shifted to lower vibrations for $90 \mathrm{~cm}^{-1}, 60 \mathrm{~cm}^{-1}$ and $40 \mathrm{~cm}^{-1}$ for dextran, pullulan and inuline complexes, respectively, compared to the non-refined complexes and $\mathrm{FeOOH}$ oligosaccharides. These results showed a stronger hydrogen bond between $\mathrm{FeOOH}$ and oligosaccharides compared to initial compounds. FTIR results, ESR spectroscopy and electron microscopy showed that particles sizes were 3-6 nm (FeOOH), 20-30 nm (inuline complex), 9-21 nm (dextran complex) and 12-26 nm (pullulan complex), and $12 \mathrm{~nm}$ (ferritin); the shape factor was 0.83 , (spherocolloid particles). The GPC suggests that complexes particles have a solid $\mathrm{FeOOH}$ core with a convolute oligosaccharides sheath. Based on the physico-chemical and morphological investigations, a two-layer spherical model of the complex is proposed (Fig. 2) according to Muller and Cox models. In this model the polymer particle $\beta_{2}-\mathrm{FeOOH}$ is wrapped with the oligosaccharide of adequate $M w$ forming a stronger hydrogen bond while the second layer is made of oligosaccharides with lower molar masses, bound together with the oligosaccharides from the first layer by weaker hydrogen bonds.

(a)

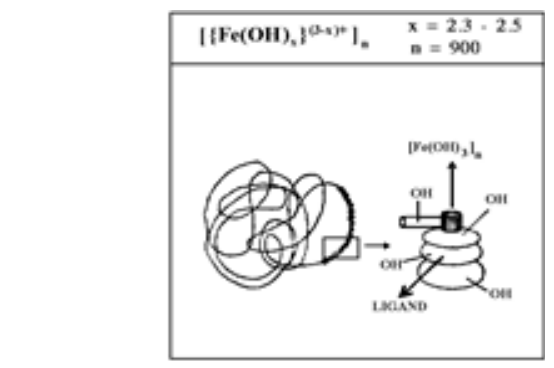

(b)

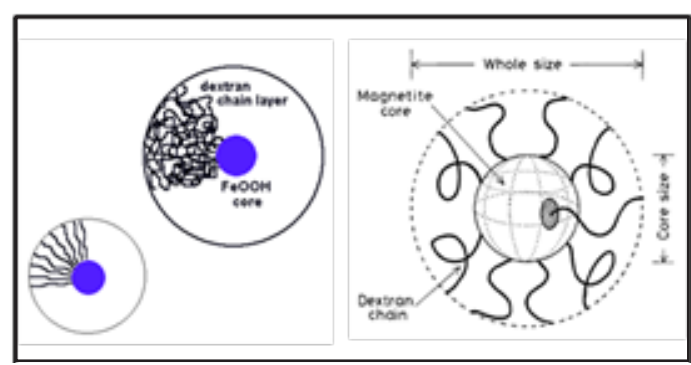

(c)

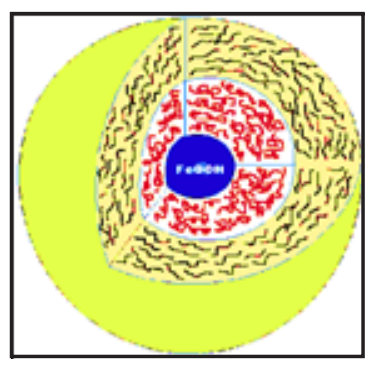

Figure 2.Structure models of polynuclear iron(III) complexes with oligosaccharides: Muller (a), Cox and Kawagughi (b) and spherical, multilayer hypothetical (c)

\section{Pharmacological study}

In the global context, the investigated synthetic $\mathrm{Fe}(\mathrm{III})$ complexes are similar to the biological protein complex with iron-ferrite, as well as the results of the pharmacological tests. Similarity of $\mathrm{Fe}$ (III) complexes to human blood-grain-erythrocyte allows their undisturbed moving through body fluids in vivo [26]. By testing acute toxicity, in the iron-inulin complex ( $\mathrm{Fe}$ content $50 \mathrm{mgcm}^{-3}$ and inulin oligomers $150 \mathrm{mgcm}^{-3}$ ), an average lethal dose of $\mathrm{LD}_{50}=525 \mathrm{mgFekg}^{-1} \mathrm{~m} . \mathrm{w}$. for mice was determined. For the iron-pullulan complex ( $\mathrm{Fe}$ content $50 \mathrm{mgcm}^{-3}$ and pullulan oligomers $\left.145 \mathrm{mgcm}^{-3}\right), \mathrm{LD}_{50}$ was $1429 \mathrm{mgkg}^{-1}$ m.w., while for the iron-dextran $\left(\mathrm{Fe}\right.$ content $50 \mathrm{mg} / \mathrm{cm}^{3}$ and dextran oligomers $\left.190 \mathrm{mgcm}^{-3}\right) \mathrm{LD}_{50}$ was higher than $2500 \mathrm{mkg}^{-1} \mathrm{~m} . \mathrm{w}$., which meets the requirements of most pharmacopoeias. Resorption studies of these complexes on rabbits have shown satisfactory results. The maximum iron concentration was achieved 36 hours after iron-inulin and iron-dextran complexes applications, as well as 24 hours after iron-pulullan complex application.

\section{Nano-Biocomplexes of Dextran and Pullulan with Copper and Cobalt}

\section{Synthesis}

Schematic presentation of synthesis and characterization of synthesized M(II)-RLMP and M(II)-RLMD complexes $(\mathrm{M}=\mathrm{Cu}, \mathrm{Co})$ is shown in Fig. 3., and described in details $[10,32-34]$.

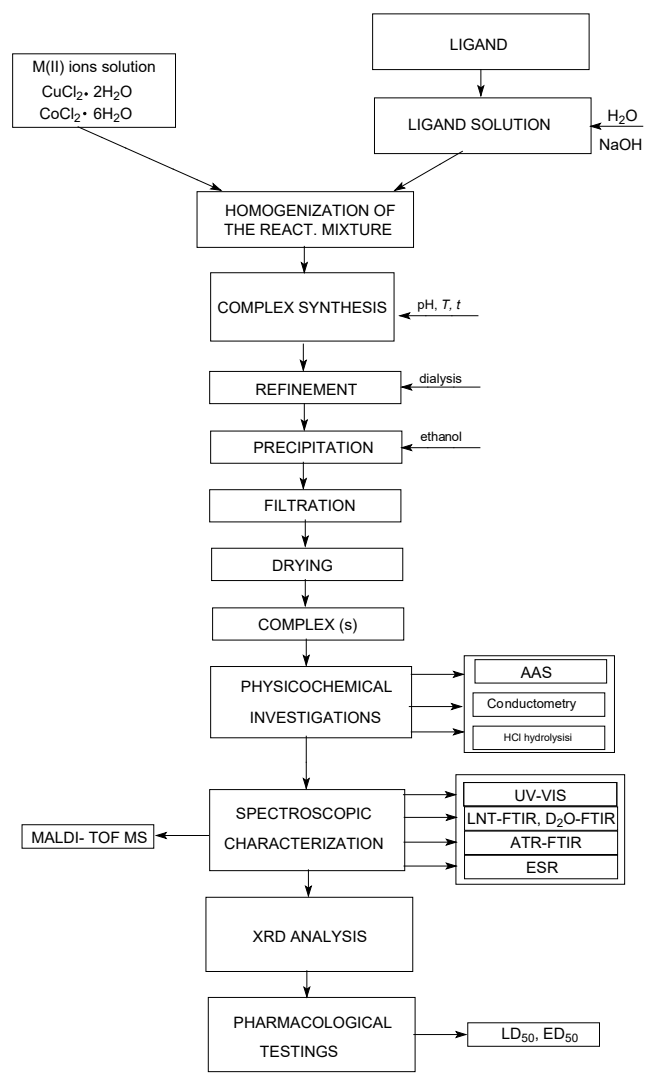

Figure 3. Schematic presentation of synthetic procedure and characterization of synthesized M(II)-RLMP/ M(II)-RLMD complexes. 
The $\mathrm{pH}$ of the reaction medium was changed after $\mathrm{Cu}(\mathrm{II})$-salt addition, reflecting the dependence of $\mathrm{pH}$ values of the $\mathrm{Cu}(\mathrm{II})$ ion content in the $\mathrm{Cu}(\mathrm{II})-\mathrm{RLMP}$ complex. In fact, when synthesis were performed at the same temperature and within the same reaction period, the highest $\mathrm{Cu}$ (II) ion content was obtained at $\mathrm{pH} 7.5$. Additionally, if the solution $\mathrm{pH}$ values increased from 7.5 to 12 , the percentage of the bound $\mathrm{Cu}(\mathrm{II})$ in the complex decreased from 13 to $\sim 8 \%$ (AAS). The increase of solution $\mathrm{pH}$ from 7.5 to 13.5 , the percentage of the bound $\mathrm{Co}$ (II) ion in the Co(II)-RLMP complex increased from $\sim 2$ to $\sim 8 \%$ (AAS). The solubility of the synthesized $\mathrm{Co}$ (II)-RLMP complexes varies in water. For comparison, the copper content in $\mathrm{Cu}(\mathrm{II})-\mathrm{RLMP}$ complexes varied from $\sim 8$ to $\sim 13 \%$ (AAS). The most water-soluble Co(II)-RLMP and Co(II)-RLMD complexes were obtained at $\mathrm{pH} 13.5$, since increased $\mathrm{pH}$ value favored formation of ionized forms of synthesized complexes leading to their better aqueous solubility. Optimal conditions for copper complexes, with respect to the metal content, are $\mathrm{pH} 7-8, T=100^{\circ} \mathrm{C}$, and $t=7$ min for the complex; Cu contents were 19.8, and $13 \%$ for $\mathrm{Cu}(\mathrm{II})-\mathrm{RLMD}$ and $\mathrm{Cu}(\mathrm{II})-\mathrm{RLMP}$, respectively. Optimal conditions for cobalt complexes, with respect to the metal content are: $\mathrm{pH} 12-13.5 ; T=100^{\circ} \mathrm{C}$, and $t=7-15 \mathrm{~min}$; Co contents were 8.35 and $12.9 \%$ for Co(II)-RLMD and Co(II)-RLMP, respectively.

\section{UV-Vis study}

The synthesis and spectroscopic characterization of the $\mathrm{Cu}(\mathrm{II})$ ion complexes with RLMP and RLMD is described in detail $[33,34,37]$.The formation of $\mathrm{Cu}(\mathrm{II})$-hydroxyl complexes with deprotonated dextran monomer unit was observed in the range of $\mathrm{pH} 8-12$. The results of spectrophotometric analysis indicate the possibility of the formation of coordination bonds which rearrangement begins at $\mathrm{pH}>8$. Synthesized $\mathrm{Cu}(\mathrm{II})$-complexes are decomposed at $\mathrm{pH}>12$. Complexes of $\mathrm{Cu}(\mathrm{II})-\mathrm{RLMD}$ and $\mathrm{Cu}(\mathrm{II})$-RLMP show different maxima of UV-Vis absorption as a function of $\mathrm{pH}$. There are typical hypsochromic (blue) shifts due to the interaction of orbitals of $\mathrm{Cu}$ (II) ion and ligands. From the Vis spectra of $\mathrm{Cu}$ (II) complexes, the wavelength interval of the absorption maximums was found to be within $\lambda=630-750 \mathrm{~nm}$ for dextran complexes and $\lambda=650-700 \mathrm{~nm}$ for pullulan complexes. According to literature, these energy values (1.8 to $2 \mathrm{eV}$ ) are in the area characteristic for the octahedral ligand field $(\Delta \mathrm{o})$.

The synthesis and spectroscopic characterization of the Co(II) ion complexes with RLMD and RLMP is described in detail $[35,36,38,39]$. With the increase in $\mathrm{pH}$ the absorbance maxima of complex solutions showed red shift compared to $\left[\mathrm{Co}\left(\mathrm{H}_{2} \mathrm{O}\right)_{6}\right]^{2+}$ ion (bathochromic effect). From the Vis spectra of Co(II) complexes, synthesized under different reaction conditions, it was possible to see that the absorbance maxima were in the range of $583-624 \mathrm{~nm}$ for dextran complexes, and $525-675 \mathrm{~nm}$ for pullulan complexes. The corresponding ligand crystal field splitting energies $(\Delta \mathrm{o})$, according to the literature data, are characteristic for the On ligand field.

The spectrophotometric parameters of the investigated complexes are characteristic for $\mathrm{Co}$ (II) ion in octahedral or tetragonal distorted octahedral coordination with $O$ ligand atoms.

\section{FTIR study}

FTIR spectroscopy method is usually the technique of choice for structural analysis of polysaccharides [40-43]. The FTIR spectra of complexes with $\mathrm{Cu}(\mathrm{II})-\mathrm{RLMD}$ and $\mathrm{Cu}(\mathrm{II})-\mathrm{RLMP}$ contain the following characteristic bands: $\mathrm{v}(\mathrm{O}-\mathrm{H}) \sim 3400 \mathrm{~cm}^{-1}, \mathrm{v}(\mathrm{C}-\mathrm{H}) \sim 2930 \mathrm{~cm}^{-1}, \delta(\mathrm{HOH}) \sim 1645$ $\mathrm{cm}^{-1}, \delta(\mathrm{C}-\mathrm{H}) \sim 1450$ and $\sim 1345 \mathrm{~cm}^{-1}, \delta(\mathrm{O}-\mathrm{H}) \sim 1420$ $\mathrm{cm}^{-1}$, a complex band $\mathrm{v}(\mathrm{C}-\mathrm{O}) 1200-1000 \mathrm{~cm}^{-1}, \mathrm{v}(\mathrm{C}-\mathrm{H})$ $1000-700 \mathrm{~cm}^{-1}$. The spectra appearance in this region is very similar for $\mathrm{Co}$ (II) complexes. It is already known that complexation of copper(II) ion with RLMP [41] and RLMD [42] gives different types of complexes, depending on the $\mathrm{pH}$ value. With the assumption that $\mathrm{Co}(\mathrm{II})$ ions formed similar complexes, bands in this region should be attributed to the stretching vibrations of ligand $\mathrm{OH}$ groups and coordinated $\mathrm{H}_{2} \mathrm{O}$ molecules for the complex synthesized in a weak alkaline solution. It should also be associated with ligand $\mathrm{OH}$ groups and the $\mathrm{OH}-$ ions in the first coordination sphere of the $\mathrm{Co}$ (II) ion for the complexes, synthesized in alkaline and strong alkaline solutions. No effect after complexation on the conformation change of $\alpha$-D-glucopyranose units with ${ }^{4} \mathrm{C}_{1}$ chair conformations was observed for the $M(I I)-R L M D$ and $M(I I)-$ RLMP complexes as evidenced by the appearance of FTIR spectra in the range of $1000-700 \mathrm{~cm}^{-1}[38,41,42]$.

FTIR spectra of RLMD and Co(II)-RLMD complexes were compared with the deconvoluted spectra of their analogues recrystallized from $\mathrm{D}_{2} \mathrm{O}$ [43-45]. FTIR spectra were measured in order to find the specific spectral peculiarities, i.e. collecting the information about structure and conformation of these macromolecules. In the range of $v(O-D)$ vibrations one new band appears at about $2495 \mathrm{~cm}^{-1}$ in the FTIR spectrum of deuterated RLMD and this is obviously the consequence of isotopic exchange in some $\mathrm{OH}$ groups whose $\mathrm{v}(\mathrm{OH})$ vibrations are manifested by the presence of a broad intensive band at about $3350 \mathrm{~cm}^{-1}$ which is an evidence of water molecules presence in RLMD structure. As for the Co(II)RLMD complex, a new band appears in the FTIR spectrum of deuterated complex synthesized at $\mathrm{pH} 13.5$ at about $2483 \mathrm{~cm}^{-1}$ in the range of $\mathrm{v}(\mathrm{O}-\mathrm{D})$ vibrations. Partners of these vibrations are expected to be $\mathrm{v}(\mathrm{O}-\mathrm{H})$ vibrations manifested by the broad intensive band at about $3400 \mathrm{~cm}^{-1}$ from water molecules. Sharp band at 3636 $\mathrm{cm}^{-1}$ in the deconvoluted FTIR spectrum of $\mathrm{Co}(\mathrm{II})-\mathrm{RLMD}$ complex may be attributed to $\mathrm{v}(\mathrm{O}-\mathrm{H})$ vibrations of the free $\mathrm{OH}$ groups which are not included in the formation of hydrogen bonds. Complete deuteration of these $\mathrm{OH}$ groups results in the disappearance of this band and appearance of a new sharp band at $2580 \mathrm{~cm}^{-1}$, originating from $v(O-D)$ vibrations in the FTIR spectrum of deuterated Co(II)-RLMD complex. 
By using Falk criteria [46], it can be concluded that both RLMD and Co(II)-RLMD complex have one crystallographic type of $\mathrm{H}_{2} \mathrm{O}$ molecule. According to the correlation of Berglund et al. [47], estimated Ow.... distances are $283.1 \mathrm{pm}$ for RLMD and $281.8 \mathrm{pm}$ for Co(II)-RLMD complex, and $\mathrm{H}_{2} \mathrm{O}$ protons take part in the formation of relatively weak hydrogen bonds. Co(II)-RLMD complexes are probably formed by the displacement of $\mathrm{H}_{2} \mathrm{O}$ molecules from the first coordination sphere of $\mathrm{Co}(\mathrm{II})$ ion by the $\mathrm{OH}$ groups of ligand.

An effect of conformation change was observed in recrystallized $\mathrm{Cu}(\mathrm{II})$-dextran complex, especially when glucopyranose units with ${ }^{4} C_{1}$ chair conformations are present, the IR spectra exhibit one band in the region between 925 to $885 \mathrm{~cm}^{-1}$ and another one around 860 to $820 \mathrm{~cm}^{-1}$, which are assigned to mixed $\mathrm{CCH}$ deformation vibrations. In the particular region, of 1000 to $700 \mathrm{~cm}^{-1} \mathrm{a}$ certain band at $880 \mathrm{~cm}^{-1}$ was considered as characteristic for the conformation change ${ }^{4} \mathrm{C}_{1}$-chair to $3 \mathrm{~B}$-boat of glucopyranose units (Fig. 4) [43].

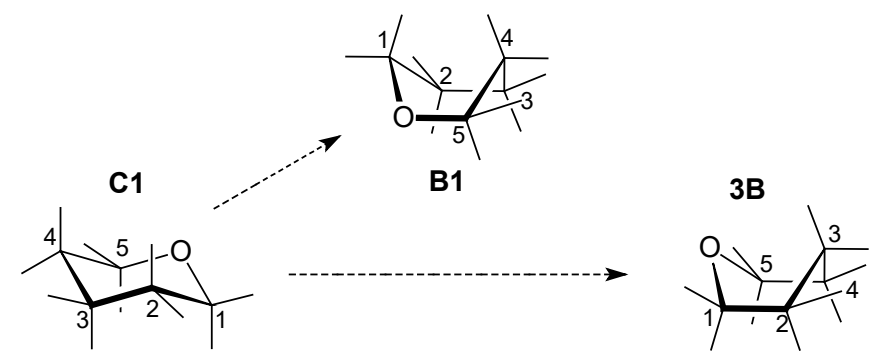

Figure 4. Change of ${ }^{4} \mathrm{C}_{1}$ chair conformation to $\mathrm{B} 1$ or $3 \mathrm{~B}$ boat conformation of the glucopyranose dextran units.

\section{ATR-FTIR study}

There are differences between FTIR microscopy images of RLMP and RLMD ligands and synthesized M(II)RLMP and M(II)-RLMD complexes, confirming that the complexation process has taken place.The changes in color contour may show the content and distribution of metal and ligand in the samples. The diameter and shape of the particles of synthesized complexes are different and depend on pH. ATR-FTIR spectra and FTIR microscopic images from different areas of complexes synthesized at $\mathrm{pH}$ 7.5-13.5 also show high homogeneity of the samples [48].

\section{ESR}

The ESR spectra of $\mathrm{Cu}(\mathrm{II})-\mathrm{RLMD}$ complexes indicate the axially elongated tetragonal distorted octahedral symmetry of synthesized $\mathrm{Cu}$ (II) ion complexes and are typical for the $\mathrm{Cu}(\mathrm{II})$ ion with one unpaired electron in $3 \mathrm{~d}$ subshell [33]. Specific values of $A_{\|}$and $g_{\|}$for $\left[\mathrm{Cu}\left(\mathrm{H}_{2} \mathrm{O}\right)_{6}\right]^{2+}$ ion are $A_{\|}=137 \times 10^{-4} \mathrm{~cm}^{-1}, \mathrm{~g}_{\|}=2.41$. ESR parameters of the spectra for the complexes synthesized at higher $\mathrm{pH}$ values were close to the values for the frozen $\mathrm{Cu}(\mathrm{II})-$ ethylene glycol complex indicating the square-planar or tetragonal distorted octahedral coordination of $\mathrm{Cu}$ (II) ion, with four oxygen atoms in the same plane. The appear- ance and ESR parameters for the spectra of complexes obtained at pH 8 and 12 were very similar to the ESR spectra of some $\mathrm{Cu}(\mathrm{II})$ ion complexes with carboxymethyl-dextran and cellulose obtained at high $\mathrm{pH}$ values $[34,37]$. Although the $\mathrm{Cu}(\mathrm{II})$ ion content of the complexes synthesized at lower $\mathrm{pH}$ values was much higher (up to $13.04 \%$ for the complex synthesized at $\mathrm{pH} 7.5$ ), the ESR signal of these complexes was lacking due to strong spin-spin interactions of neighboring $\mathrm{Cu}(\mathrm{II})$ ions, and probably due to the formation of polynuclear $\mathrm{Cu}$ (II) complexes. All ESR parameters observed from $\mathrm{pH} 7.5-12$ differ, especially in A॥ and g॥ from the parameters of $\left[\mathrm{Cu}\left(\mathrm{H}_{2} \mathrm{O}\right)_{6}\right]^{2+}$ ion and $\left[\mathrm{Cu}(\mathrm{OH})_{4}\right]^{2-}$ ion $\left(\mathrm{A}_{\| l}=194 \times 10^{-4} \mathrm{~cm}^{-1}\right.$, $\mathrm{g}_{\|}=2.271$ ). This indicates that $\mathrm{O}-$ donors from deprotonated $\mathrm{OH}$ groups may participate in $\mathrm{Cu}(\mathrm{II})$ ion coordination. A decrease of gll values with the increase of $\mathrm{pH}$ complex solutions also confirms the presence of different types of complexes. This conclusion is in accordance with the results obtained by UV-Vis investigations.

\section{XRD}

The crystallinity/amorphicity changes caused by the complexation of RLMP with Co(II) ions was observed by using XRD analysis. The crystallinity of the final product gradually rose with increased concentration of introduced $\mathrm{Co}$ (II) ions. Furthermore, in the XRD pattern of $\mathrm{Co}(\mathrm{II})-\mathrm{RLMP}$ complex obtained at $\mathrm{pH} 13.5$, only several diffraction peaks at $2 \theta$ values of $19^{\circ}, 32.5^{\circ}$, and $38^{\circ}$ were present, which suggests that $\mathrm{Co}(\mathrm{II})-\mathrm{RLMP}$ complexes still had low degree of crystallinity after the complexation [32].

\section{MALDI-TOF MS}

Shape of peak intensities distribution in the 100010000 Da range with apparent maximum around 3500 $\mathrm{Da}$ indicates that additional depolymerization of pullulan occurred during complex synthesis. Adjacent peaks in this $\mathrm{m} / \mathrm{z}$ range differ by approximately $162 \mathrm{Da}$ which corresponds to the anhydro-glucopyranose moiety. The MALDI-TOF/TOF MS in the 450-2000 Da range also contains peaks differing by $162 \mathrm{Da}$, but some adjacent peaks differ by approximately $59 \mathrm{Da}$ corresponding to the cobalt loss from these low molar mass fragments. Since peaks with $\mathrm{m} / \mathrm{z}$ difference of $59 \mathrm{Da}$ do not appear in the 1000-10000 Da range it can be concluded that Co(II)-HNMP complex synthesized at $\mathrm{pH} 13.5$ is very stable, while $\mathrm{Co}$ (II) ion binding in low molar mass fragments is much weaker. The MALDI-TOF/TOF MS of different $\mathrm{Co}(\mathrm{II})$-HNMP complexes also show the repeating unit of mass $162 \mathrm{Da}$ which corresponds to the anhydroglucopyranose moiety. In addition to the series of peaks with a $162 \mathrm{Da}$ gap, there is a minor series with a $486 \mathrm{Da}$ increment corresponding to the mass of anhydro-maltotriose moiety [32].

\section{Structure}

Based on the correlation of data obtained by different spectroscopic techniques for the characterization 
of synthesized M(II)-RLMP and M(II)-RLMD complexes, the structure with tetragonal distorted Oh coordination for the synthesized complexes was proposed. M(II) ions form three different types of complexes with glucopyranose units (Glcp): a) $\mathrm{M}(\mathrm{II})(\mathrm{Glcp})_{2}\left(\mathrm{H}_{2} \mathrm{O}\right)_{2}$ at pH 7-8, b) $\mathrm{M}(\mathrm{II})$ $(\mathrm{Glcp})_{2}\left(\mathrm{H}_{2} \mathrm{O}\right)(\mathrm{OH})$ at pH 8.5-10, and c) $\mathrm{M}(\mathrm{II})(\mathrm{Glcp})_{2}(\mathrm{OH})_{2}$ at $\mathrm{pH}$ 11-13.5). The proposed structures of the complexes synthesized at different $\mathrm{pH}$ values are given in Fig. 5 .

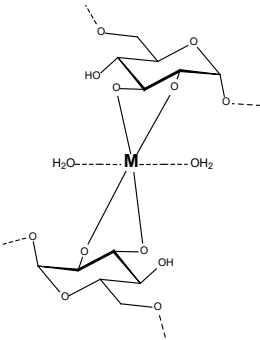

(a)

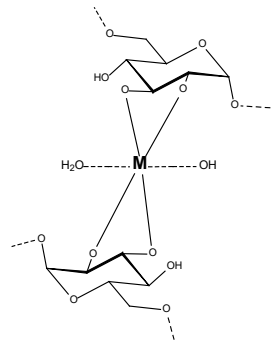

(b)

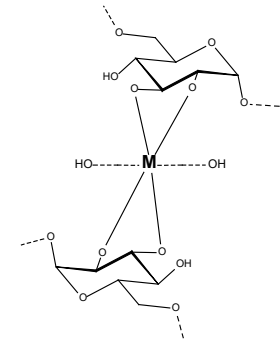

(c)
Figure 5. Proposed structures of M(II)-RLMP and M(II)-RLMD complexes synthesized at different $\mathrm{pH}$ values: a) at $\mathrm{pH}$ 7-8: $\left.\mathrm{Co}(\mathrm{II})(\mathrm{Glc})_{2}\left(\mathrm{H}_{2} \mathrm{O}\right)_{2}, \mathrm{~b}\right)$ at pH 8.5-10: $\left.\mathrm{Co}(\mathrm{II})(\mathrm{Glc})_{2}\left(\mathrm{H}_{2} \mathrm{O}\right)(\mathrm{OH}), \mathrm{c}\right)$ at $\mathrm{pH}$ 11-13.5: $\mathrm{Co}(\mathrm{II})(\mathrm{Glc})_{2}(\mathrm{OH})_{2}$.

\section{Pharmacology}

The preparation was tested pharmacologically with the aim of determining systemic acute toxicity expressed as a median lethal dose (LD50) and as an equivalent of $\mathrm{Cu}$ (II) dose per $\mathrm{kg}$ of a mouse body weight. The application of higher doses caused the mortality of a number of experimental animals. The preparation toxicity $L_{50}$ of 1419-1661 was determined in this range which corresponds to the equivalent of $\mathrm{Cu}(\mathrm{II})$ dose of $281-329 \mathrm{mg}$ per $\mathrm{kg}$ of the body weight (concentration of the complex solution $5-20 \%$ ). The results of our pharmacological investigations suggest to the lower toxicity of $\mathrm{Cu}$ (II) complex with RLMD, what is much better than in the case of commercially applicable inorganic copper salts [49]. This result is very important for the development of new pharmaceutical preparations and it can be applicable in medicine and cosmetology.

Nanoparticle (complexes) of biometals $\mathrm{Cu}$ and $\mathrm{Co}$ with CMD and DS

\section{Physico-chemical characteristics of the $\mathrm{Cu}$ and $\mathrm{Co}$} complexes

Copper and cobalt complexes with carboxymethyl dextran (CMD, $\left.M w=80000 \mathrm{gmol}^{-1}\right)$ and sodium salts of dextran sulfate (DS, $M w=500000 \mathrm{gmol}^{-1}$, see Fig. 6) were synthesized from aqueous solutions of $\mathrm{Cu}\left(\mathrm{CH}_{3} \mathrm{COO}\right)_{2}$ and $\mathrm{CoCl}_{2} \times 6 \mathrm{H}_{2} \mathrm{O}$ in the molar ratio of 2:1 at boiling temperature. The synthesis of cobalt and copper complexes was monitored by color change from colorless to pink and green, respectively, and new absorption maxima appearance in the visible part of the spectra. The higher metal content and yield were achieved after 60 minutes of reaction. The molar ratio of both metals with $\mathrm{CMD}$ and DS was 2:1 and 1:1, respectively $[22,50]$.

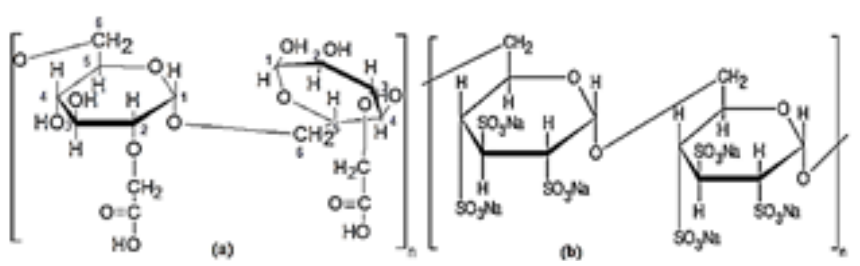

Figure 6. Structure of carboxymethil dextran, CMD (a) and sodium salt of dextran sulphate, DS (b)

Spectra-structural correlations

Copper-CMD and -DS complexes showed bends maxima at $\sim 750$ and $\sim 510 \mathrm{~nm}$, respectively, in the UV-Vis spectra, while cobalt-CMD and -DS complexes showed bends maxima at $\sim 710$ and $\sim 500 \mathrm{~nm}$, respectively. The absorption maxima for DS complex were at lower wavelengths ( 10 or $\sim 40 \mathrm{~nm})$ compared to maxima of CMD complex, indicating stronger metal-O interactions in DS complexes. The absorption maxima of cobalt complex exhibit a hypochromic effect in relation to the corresponding copper complexes, indicating stronger Co-O interactions compared to $\mathrm{Cu}-\mathrm{O}$. Calculations of molar energy content $\left(161 \mathrm{kJmol}^{-1}\right)$ and crystalline field splitting energy $(1.74 \mathrm{eV})$, indicate the formation of tetragonal deformed complexes of octahedral configuration in Cu-CMD, while for $\mathrm{Cu}$-DS the corresponding values are $171 \mathrm{kJmol}^{-1}$ and $1.85 \mathrm{eV}[22,50]$.

The efficiency of synthesis process was confirmed by spectra-structural correlations based on FTIR studies, changes in the vibrations of all types of $\mathrm{OH}$ functional groups, and the absence of $\mathrm{v}(\mathrm{C}-\mathrm{OH})$ vibration. This vibration is absent in the spectra of CMD and DS, but not in the spectra of complexes. In the same time, the $\mathrm{v}(\mathrm{Co}-\mathrm{O})$ and $\mathrm{v}(\mathrm{Cu}-\mathrm{O})$ vibrations were found at $\sim 580 \mathrm{~cm}^{-1}$ in the spectra of complexes, but not in CMD and DS spectra. The similarities of the $\mathrm{Y}(\mathrm{C}-\mathrm{H})$ ranges, in a low frequencies part of the spectra, indicate that there is no difference in the conformation of the ${ }^{4} \mathrm{C} 1$ glucopyranose unit between $\mathrm{CMD}$ and DS and synthesized $\mathrm{Cu}(\mathrm{II})$ or $\mathrm{Co}(\mathrm{II})$ complexes. Analysis of FTIR spectra in the region of valent $(C=O)$ vibration showed that $-\mathrm{COOH}$ group acts as bidentate ligand, while the compounds of $\mathrm{Cu}(\mathrm{II})$ or $\mathrm{Co}(\mathrm{II})$ with DS metal ions are in the region of four oxygen atoms of two adjacent sulfo groups. The presence of crystalline water was determined by isotopic substitution of $\mathrm{H}_{2} \mathrm{O}$ with $\mathrm{D}_{2} \mathrm{O}$ molecules. Comparison of spectra measured at room temperature (RT) and liquid nitrogen temperature (LNT) allowed detection of water molecules libration indicating that they are coordinated complementing coordination sphere of $\mathrm{Cu}(\mathrm{II})$ ions to six. The bands of valent $(\mathrm{S}=\mathrm{O})$ vibrations in $\mathrm{Cu}$ and $\mathrm{Co}$ complexes were at lower frequencies for $\sim 12 \mathrm{~cm}^{-1}$ compared to DS. The similarity of FTIR spectra, originating from DS sodium salt or $\mathrm{Cu}$ and Co complexes, indicates the predominantly ionic character of these compounds. A band of $\operatorname{Vas}(\mathrm{O}-\mathrm{S}-\mathrm{O})$ at $\sim 810 \mathrm{~cm}^{-1}$ 
(vibrations of DS sulfo group in the equatorial position) was shifted to $\sim 850 \mathrm{~cm}^{-1}$ in the spectra of $\mathrm{Cu}$ and $\mathrm{Co}$ complexes, indicating a change in the position of this group in the axial plane [22,50]. The complexes were of $\mathrm{M}(\mathrm{II}) \cdot(\mathrm{CMD})_{2} \cdot\left(\mathrm{H}_{2} \mathrm{O}\right)_{2}$ or $\mathrm{M}(\mathrm{II}) \cdot \mathrm{DS} \cdot\left(\mathrm{H}_{2} \mathrm{O}\right)_{2}$ type (Fig.7).

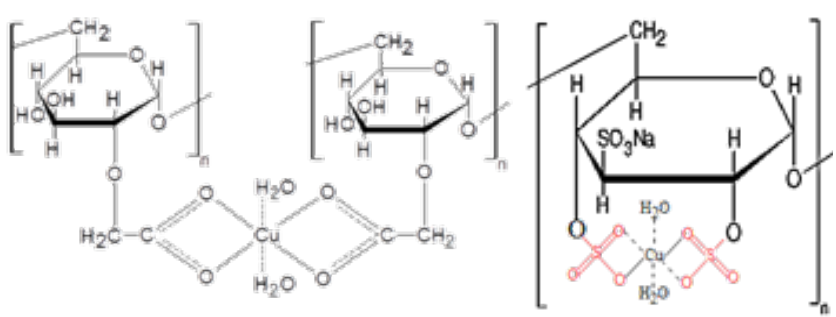

Figure 7. Proposed structures of $\mathrm{M}(\mathrm{II})-\mathrm{CMD}$ and $\mathrm{M}(\mathrm{II})-\mathrm{DS}$ complexes

\section{Silver Nanoparticle with CMD and DS and Water extracts of Fumaria officinalis $\mathrm{L}$.}

\section{Synthesis procedure}

The synthesis was performed until the defined Ag:L (DS or CMD) ratio (from $1: 1$ to $1: 2$ ) at $100{ }^{\circ} \mathrm{C}$ was achieved with continuous stirring in the duration of 120 min. A successful synthesis of the AgNPs-CMD or AgNPs-DS complex was identified through the color changes of the reaction mixtures, from white to yellow [51,52]. Water extracts (E) of Fumaria officinalis L. (earth smoke), according to literature data [53], contain alkaloids, flavonoids, carbohydrates, glycosides, tannins, saponins, proteins, steroids and organic amino acids, the phytochemicals with different functional groups which can reduce $\mathrm{Ag}^{+}$to $\mathrm{Ag}^{0}$ additionally acting as capping agents. Green synthesis of AgNPs with the extract of Fumaria officinalis L. was performed in alkaline solution at room and boiling temperatures [54].

\section{UV-Vis study}

Strong absorption band in UV-Vis spectra, called SPR (surface plasmon resonance) band at $420 \mathrm{~nm}$, is characteristic for AgNPs formation. Its exact position mostly depends on AgNPs size, while intensity depends on AgNPs concentration [55]. Changes in this band position were used as a criterion of the AgNP aggregation stability monitoring. The position of this band in AgNPsDS was changed during synthesis. After $2 \mathrm{~h}$ of synthesis it remained constant at $425 \mathrm{~nm}$ indicating particle size of $\sim 40 \mathrm{~nm}$. SPR band in the AgNPs-CMD spectrum, synthesized in different molar ratio, was located at $420 \mathrm{~nm}$ indicating particle size of $20-40 \mathrm{~nm}$; the intensity of this band is proportional to AgNPs-CMD concentration. Unchanged position of SPR band is an evidence of high aggregation stability of the reaction mixture for 3 months at room temperature. The region of UV spectra below 300 $\mathrm{nm}$ was monitored for first time according to available literature [51,52,54]. An intensive band at $215 \mathrm{~nm}\left(\pi \rightarrow \pi^{*}\right.$ transition of the carboxyl group) in the UV spectra of formed complex [56] indicates red shift effect compared to CMD. This phenomenon is an additional indicator of $\mathrm{Ag}$ ions and CMD interaction i.e. AgNP-CMD complex formation.

According to UV-Vis study it can be concluded that synthesis of AgNPs-E at boiling temperature was much faster (30 $\mathrm{min}$ ) compared to synthesis at room temperature (90 min). The unchanged position of the SPR band indicates good aggregates stability of particles with the size of approximately $18 \mathrm{~nm}$. The intensity of $\pi \rightarrow \pi^{*}$ and $\mathrm{n} \rightarrow \pi^{*}$ bands (200-350 nm) for AgNPs-E were significantly reduced compared to extract itself due to reduction of silver ions by functional groups which possess free electron pairs ( $\mathrm{CO}$ or amide).

\section{XRD study}

Crystal structure of AgNPs-DS, AgNPs-CMD and AgNPs-E nanoparticles was confirmed by Xray diffraction (XRD) technique. For surface-cantered cubic grid of silver the characteristic peaks are at $2 \theta, 38.2^{\circ}, 44.4^{\circ}$, $64.7^{\circ}$ and $77.4^{\circ}$ corresponding to the (111), (200), (220) and (311) reflection planes, respectively. All samples exhibited the characteristic peaks at this $2 \theta$ positions. The average size of the AgNPs was estimated from the reflection width in the X-ray diffraction pattern according to the Scherrer equation, using the Bragg reflection at $2 \theta=38.2^{\circ}$ and $44.4^{\circ}$. The average crystallite size of the AgNPs-E synthesized at room and boiling temperature was $20+/-1$ and $18+/-1 \mathrm{~nm}$, respectively; in the case of AgNPs-DS the average crystallite size was $40 \pm 4 \mathrm{~nm}$ $[51,52,54,57]$.

\section{SEM and EDX analysis}

The morphology of the AgNPs-CMD, AgNPs-DS and AgNPs-E was studied by SEM analysis. In the AgNPsCMD stable and spherical particles of $10-60 \mathrm{~nm}$ are dominant. The size of AgNPs-DS was similar, but the appearance of aggregates with an irregular structure without a well-defined morphology was noticed $[52,54]$. SEM micrographs of AgNPs-E nanoparticles showed spherical particles with an average size of $25 \mathrm{~nm}$ and the presence of small aggregates.

EDX spectroscopy was used for qualitative and quantitative analysis of silver involved in formation of AgNPsDS and AgNPs-E. All samples showed strong signals corresponding to elemental silver at $3 \mathrm{keV}$. Lower signals from $S$ or $C$ and $O$ confirm the formation of AgNPs as a part of AgNPs-DS or AgNPs-E. After calibration, the content of Ag was approximately determined by INCA software as $35 \%$ and $70 \%$ in the AgNPs-E formed at room and boiling temperatures, respectively $[52,54]$.

\section{FTIR study}

The FTIR spectra of AgNPs-CMD and AgNPs-DS were basically very similar to the spectra of copper and cobalt complexes with these ligands. The ${ }^{4} \mathrm{C} 1$ conformation of the glucopyranose unit i.e. the high content of $\alpha-1,6$ linkage remained unchanged after complexation. Here, the carboxyl group of CMD again played the role 
of a bidentate ligand. There were strong interactions between $\mathrm{Ag}$ and two $\mathrm{O}$ atoms from the -COO groups in the Oh environment, bonding the CMD with AgNPs. There was a difference in the position of $\mathrm{v}_{\mathrm{as}}(\mathrm{S}=\mathrm{O})$ band, in the FTIR spectrum of AgNPs-DS compared to DS, for about $22 \mathrm{~cm}^{-1}$. A similar situation was in the complexes with copper and cobalt, indicating predominantly ionic interactions between sulfo groups from DS with AgNPs.

The detection of water molecules libration was enabled using isotope substitution method (deuteration) and the spectra measured by RT and LNT comparing. The presence of coordinated complementing coordination sphere of $\mathrm{Cu}(\mathrm{II})$ or $\mathrm{Co}(\mathrm{II})$ ions to six was indicated. The absence of a band at $\sim 1380 \mathrm{~cm}^{-1}$ in the spectra of dialyzed analogues, that originates from $\mathrm{v}_{\mathrm{as}}(\mathrm{O}=\mathrm{N}=\mathrm{O})$ of residual nitrate ions, practically confirms the real origin of this band.

The comparison of FTIR spectra measured for AgNPs-E and $E$, in amide region (Amid $\mathrm{I}-\mathrm{v}(\mathrm{C}=\mathrm{O})$ and $\mathrm{Amid}$ $\mathrm{II}-\delta(\mathrm{N}-\mathrm{H})$ at 1620 and $1530 \mathrm{~cm}^{-1}$, respectively), and/or $\mathrm{v}(\mathrm{C}=\mathrm{O}), \mathrm{v}(\mathrm{C}-\mathrm{O}), \mathrm{v}(\mathrm{C}-\mathrm{O}-\mathrm{C})$ and $\delta(\mathrm{OH})$ vibration, leads to the conclusion that bonds were formed between secondary amide group $(\mathrm{NH}) \mathrm{C}=\mathrm{O}$, keto or hydroxyl groups from the AgNPs-E and Ag ions. The compounds participating in reduction and stabilization of AgNPs could be polyphenols, flavonoids, triterpenoids, proteins or acids and polysaccharides [54]. Bearing in mind everything mentioned above, the proposed structure of all AgNPs is presented in Fig. 8 .

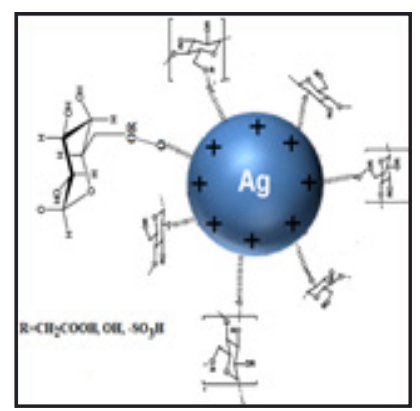

Figure 8. Proposed structures of AgNPs with CMD, DS and E

Table 1. Radial diameters of inhibition zones for bacterial and fungal strains treated by AgNPs in different concentrations

\begin{tabular}{|c|c|c|c|c|c|c|c|c|c|}
\hline \multirow{2}{*}{\multicolumn{2}{|c|}{ Temperature }} & \multirow{2}{*}{\multicolumn{2}{|c|}{$\begin{array}{c}\text { Room } T \\
\text { AgNPs-E }\end{array}$}} & \multirow{2}{*}{\multicolumn{2}{|c|}{$\begin{array}{l}\text { boiling } T \\
\text { AgNPs-E }\end{array}$}} & \multicolumn{4}{|c|}{ boiling $T$} \\
\hline & & & & & & \multicolumn{2}{|c|}{ AgNPs-CMD } & \multicolumn{2}{|c|}{ AgNPs-DS } \\
\hline \multicolumn{2}{|c|}{ Concentration $\left(\mathrm{mg} \mathrm{ml}^{-1}\right)$} & 1 & 0.5 & 1 & 0.5 & 0.5 & 1 & 0.5 & 1 \\
\hline & B. cereus & 25 & 17 & 25 & 21 & 18 & 19 & 12 & 14 \\
\hline & B. luteus & 25 & 23 & 20 & 22 & 21 & 24 & 13 & 20 \\
\hline & B. subtilis & $\mathrm{x}$ & $\mathrm{x}$ & $\mathrm{x}$ & $\mathrm{x}$ & 17 & 19 & $\mathrm{x}$ & $\mathrm{x}$ \\
\hline & L. monocitogenes & 22 & 20 & 23 & 20 & 17 & 18 & $\mathrm{x}$ & $\mathrm{x}$ \\
\hline & P. aeruginosa & 26 & 22 & 24 & 23 & 24 & 26 & - & 12 \\
\hline & K. Pneumoniae & 24 & 22 & 21 & 22 & 18 & 19 & 14 & 15 \\
\hline & E. coli & 25 & 23 & 23 & 22 & 18 & 21 & $\mathrm{x}$ & $\mathrm{x}$ \\
\hline & P. vulgaris & 28 & 25 & 25 & 22 & 14 & 15 & $\mathrm{x}$ & $\mathrm{x}$ \\
\hline Fungal strain & C. albicans & 18 & 13 & 17 & 15 & - & 16 & - & 11 \\
\hline
\end{tabular}

Comparative analysis of AgNPs antimicrobial activity

It is already known that silver nanoparticles exhibit the antimicrobial activity [12-21,58]. Radial diameters of inhibition zones for gram positive $(\mathrm{G}+)$ and gram negative (G-) bacterial as well as fungal strains, treated by different concentrations of synthesized AgNPs with CMD, $\mathrm{DS}$ and $\mathrm{E}$, are presented in Table 1.

The size of radial inhibition zones decreases in the order: AgNPs-E > AgNPs-DS > AgNPs-CMD. The inhibition zones are higher in almost all cases where the concentration of AgNPs is higher. The synthesized AgNPsE showed better antimicrobial properties compared to starting water extracts of Fumaria officinalis L. which is explained by synergistic effect of silver and extract compounds [54]. These results indicate the potential use of synthesized AgNPs-E as a raw material in various pharmaceutical and cosmetic preparations design

\section{References}

[1] J. J., Ramsten (2014) What is Nanotechnology? Applied Nanotechnology, Second Edition. http://dx.doi. org/10.1016/B978-1- 4557-3189-3.00001-4

[2] V. Trajković, Z., Marković, (2010) Nanomedicina: Stanje i perspektiva. In book: Biomaterijali. Rakovic D., Uskoković D. (eds), Institut tehničkih nauka Srpeke akademije nauke i umetnosti, Beograd, 762

[3] S. Horikosi, N. Sorpone, Microwaves in Nanoparticle Synthesis: Fundamentals and Applications 1. Introduction to Nanoparticles Published Online: 26 APR 2013 DOI: 10.1002/9783527648122.ch1

[4] V. Gibson, E. Marshall, Comp. coord. Chem. II, 9, (2003), 411

[5] P.O. Brien, N. Pickett, Comp. coord. Chem. II, 9 (2003) 1005

[6] B. Graczykovski, A. Dobek, J. Coll. Interf. Sci., 363 (2011) 551

[7] I. lakovidis, I. Delimaris, S.M Piperakis, Mol. Biology 
Internat. Article ID 594529, 13 pages, (2011) doi: $10.4061 / 2011 / 594529$

[8] S. Tsiliou, S. Kefala, L.A. Perdih, F. Turel, I. Kessissoglou, D.P. Psomas G, Europ. J. of Med. Chem. 48 (2012) 132

[9] M. Gielen, ER., Tiekink, Metallotherapeutic drugs and metal-based diagnostic agents: the use of metals in medicine. John Wiley \& Sons 2005

[10] Ž. Mitić, M. Cakić, Acta Med. Medianae 53(4) (2014) 5463.

[11] G. Nikolić and M. Cakić, Fourier Transforms-New Analytical Approaches and FTIR Strategies. Goran Nikolić, (Eds) InTech, Rijeka 2011.

[12] Y. Mohan, K. Lee, T. Premkumar, K. Geckele,r Polym. 48(1) (2007) 158

[13] V, Thomas, M. Yallapu , B. Sree dhar, S Bajpai J. Coll. Interf. Sci. 31 (2007) 389

[14] A. Panáček, M. Kolář, R. Večeřová, R. Prucek, J. Soukupová, V. Kryštof, P.Hamal, R. Zbořil . L. Kvítek, Biomat. 30: (2009). 6333

[15] Q. H. Tran, V. Q. Nguyen and A.T. Le, Nanosci. Nanotechnol. 403300 (2013) 20

[16] J. Devis, B. Bhimba (2012) 1: 242. doi:10.4172/ scientificreports.242, Page 1-5.

[17] S. Bekkeri, IOSR J. Of Pharm., 4 (7) 201438

[18] Y. Mohanta, Sujogya K. Panda, K. Bastia, T. Mohanta, Frontiers in Microbiol. 8 (2017) 1

[19] D. Van Phu, Duy, Q. Hien, Rad. Phys. Chem. 88: (2013) 90-4.

[20] J. Kim., B. V. der Bruggen, Environmen. Poll. 158(7) (2010) 2335

[21] S. Arora, J. Rajwade, P. Omray S. Khandelwal K. Paknikar). Mol. Pharmacol. 6(5) (20091388

[22] S.. Glišić, Doktorska disertacija, Tehnološki fakultet Leskovac, 2017

[23] S.K., Srikar, D.D. Giri, D.B. Pal, P.K. Mishra, S.N. Upadhyay, Green Sustainb. Chem , 6 (2016) 34

[24] A. Muller, Arznneim. Forsch. (Drug Res.), 24, 6. (1974) 880

[25] Lj. Ilić, S. Ristić. M. Cakić. G. Nikolić, S. Stanković, PCT WO 02/46241 A2 June 2002, IP Cl. C08B 37/00.

[26] G. Nikolić, Sinteza, Fizičkohemijska svojstva i struktura gvožđa(III) kompleksa sa oligosaharidima, Doktorska disertacija, Tehnološki Fakultet Leskovac, 2001.

[27] M. Cakić, G.Nikolić, D. Cvetković, Lj. Ilić, Kompleksi Fe(III) sa oligosaharidima - Antinemici, Monografija, Tehnološki fakultet, Leskovac 2007

[28] G. Nikolić, M. Cakić, Colloid. J, 69(4) (2007) 464

[29] J. Cox, G. Kenedy, P. Marshall, D. Rutherford, J. Pharm. Pharmacol. 24 (1972) 513

[30] G. Nikolić, M. Cakić D. Cvetković, Lj. Ilić, Spectrosc. Lett. 29, (1996) 7

[31] M. Cakić, G.Nikolić, Lj. Ilić, Bull. Chem. Technol. Macedonia, 21 (2). (2002) 135

[32] Ž. Mitić, G.M. Nikolić, M. Cakić, G.S. Nikolić, S. Živanović, S. Mitić, S. Najman, Carbohyd. Pol. 200 (2018), 25

[33] Ž. Mitić, M. Cakić, G.M. Nikolić, R. Nikolić, G.S. Nikolić, R. Pavlović, E. Santaniello, Carbohud. Res. 346(3) (2011), 434.

[34] Ž. Mitić, G.S. Nikolić, M. Cakić, R. Nikolić, Lj. Ilić, Russ. J. Phys. Chem. A, 81(9) (2007), 1433

[35] G. Nikolić, M. Cakić, Ž. Mitić, 2th European Chemistry Congres, Torino, Italy, 2008, CD-ROM

[36] G. Nikolić, M.D. Cakić, Ž.J. Mitić, G.S. Nikolić, R.S. Nikolić, Lj.A. Ilić, , Hem. Ind. 61(5) (2007), 257
[37] G. Nikolić, M. Cakić, Ž. Mitić, R. Nikolić, Lj. Ilić, , Hem. Ind. 59(1-2) (2005), 9

[38] Ž. Mitić, G. M. Nikolić, M. Cakić, S. Mitić , G. S. Nikolić, S. Najman , Acta F. Med. Naiss., 35(1) (2018), 37

[39] G. Nikolić, M. Cakić, S. Glišić, D. Cvetković, Ž. Mitić, D. Marković, in Fourier Transforms - High-tech Application and Current Trends, G. Nikolic, M. Cakic, D. Cvetkovic (Eds.), InTech, Rijeka 2017, p. 149.

[40] Ž. Mitić, A. Stolić, S. Stojanović, S. Najman, N. Ignjatović, G. Nikolić, M. Trajanović, Mat. Sci. Eng. C, 79 (2017), 930-949.

[41] M. Cakić, Ž. Mitić, G.S. Nikolić, Lj. Ilić, G.M. Nikolić, Spectrosc. Int. J., 22(2-3) (2008), 177

[42] Ž. Mitić, G.S. Nikolić, M. Cakić, P. Premović, Lj. Ilić, J. Mol. Struc., 924-926 (2009), 264

[43] G. Nikolić, M. Cakić, Ž. Mitić, Lj. Ilić, , Russ. J. Coor. Chem., 34(5) (2008), 322

[44] Ž. Mitić, M. Cakić, G. Nikolić, Spectrosc. Int. J., 24(3,4) (2010), 269

[45] Ž. Mitić, M. Cakić, G.S. Nikolić, Lj. Ilić, M. Stanković, Hem. Ind., 64 (1) (2010), 9

[46] G. Brink, M. Falk, Spectrochim. Acta A 27(9) (1971), 1811

[47] B. Berglund, J. Lindgren, J. Tegenfeldt, J. Mol. Struct. 43(2) (1978), 179

[48] G.S. Nikolić, M. Cakić, Ž. Mitić, B. Ilić, P. Premović, A, Russ. J. Phys. Chem. A, 83(9) (2009), 1520

[49] M. Cakić, Ž. Mitić, G. Nikolić, I. Savić, I. Savić, Expert Opin Drug. Disc., 8(10) (2013), 1253

[50] S. Glišić, G. M. Nikolić, M. D. Cakić, N. V. Trutić, Russ. J. Phys. Chem. A, 89(7), (2015), 1254

[51] S. Glišić, M. Cakić, G. Nikolić, B. Danilović, J. Mol. Struc., 1084 (2015), 345-351.

[52] M. Cakić, S. Glišić, G. Nikolić, G. M. Nikolić, K. Cakić and M. Cvetinov, J. Mol. Struc., 1110 (2016), 156-

[53] Lj. Stanojević, J. Zvezdanović, B. Danilović, D. Cvetković, J. Stanojević, D. Ilić, M. Cakić, Adv. Technol, 7(2) (2018) 31.

[54] M. D , Cakic, S. Glisic, D. Cvetkovic, M. Cvetinov, Lj. Stanojevic, B. Danilovic, K. Cakic, Coll. J. 80 (6) (2018) 803

[55] N. Bednar, PhD Thesis, University of Novi Sad, Serbia, (2014)

[56] S.A. Hapse, P.T. Kadaskar, A.S. Shirsath, Der Pharm. Lett. 3 (6) (2011) 18

[57] A. Clearfield, J. Reibenspies, and N. Bhuvanesh, Principles and Applications of Powder Diffraction, NewYork: Wiley, 2008.

[58] Bar, H., Bhui, D.K., Sahoo, G.P., Sarkar, P., De, S.P., and Misra, A., Colloids Surf. A, 339, (2009), 134. 
Izvod

\section{NANO-BIOKOMPLEKSI NA BAZI OLIGOSAHARIDA I NJIHOVIH DERIVATA}

Milorad Cakić1, Goran S. Nikolić ${ }^{1}$, Žarko Mitić ${ }^{2}$, Slobodan Glišić ${ }^{1}$, Dragan Cvetković1, Ljiljana Stanojević ${ }^{1}$

1 Univerzitet u Nišu, Tehnološki fakultet, Leskovac, Srbija

2Univerzitet u Nišu, Medicinski fakultet, Niš, Srbija

Predmet ovog rada je razvoj novih nano-biokompleksa gvožđa, kobalta i bakra na bazi oligosaharida (dekstran, pullulan, inulin) kao i kompleksa bakra i kobalata sa dekstran sulfatom i karboksi metil dekstranom i nanočestica srebra sa derivatima ovih oligosaharida i vodenim ekstraktom Fumaria officinalis L. Ispitivan je uticaj konstitucije liganda na ishod sinteze, prikazani su i rezultati fizičko-hemijskih i spektroskopskih metoda ispitivanja (HPLC, GFC, FTIR, ESR, XRD, EDX, SEM, TEM, UV-Vis, AAS) na osnovu kojih su predloženi modeli strukture ispitivanih nano-biokompleksa. Rezultati ispitivanja stabilnosti i farmako-biološke aktivnosti ukazuju na moguću primenu za izradu različitih farmaceutskih, kozmetičkih i drugih preparata za primenu u humanoj medicini, veterini, kozmetici i drugim oblastima.
(ORIGINALNI NAUČNI RAD) UDK 547.458:541.49

Ključne reči: nano-biokompleksi, gvožđe, bakar, kobalt, srebro, oligosharidi, farmako-biološke karakteristike. 